\title{
OA02.03. Nutrient biomarker patterns and rates of cognitive decline in dementia-free elders
}

\author{
G Bowman*, J Quinn, J Kaye, J Shannon \\ From International Research Congress on Integrative Medicine and Health 2012 \\ Portland, Oregon, USA. 15-18 May 2012
}

\section{Purpose}

We previously identified three distinct nutrient biomarker patterns associated with both psychometric and neuroimaging indices of brain health in a cross-sectional analysis. The objective of this study was to examine the relationship between the nutrient biomarker patterns and cognitive decline over 2 years.

\section{Methods}

Thirty biological markers of diet were assayed in plasma from 104 dementia-free elders in the Oregon Brain Aging Study. Principal component analysis constructed distinct nutrient biomarker patterns. A linear regression model was used to assess the association between NBPs and rate of change in Clinical Dementia Rating - sum of box score over two years.

\section{Results}

Mean age was $87 \pm 10,62 \%$ were female, and $10 \%$ were carrying the ApoEe4 allele. Two distinct nutrient biomarker patterns were associated with rates of cognitive decline: a vitamin pattern high in $\mathrm{B}, \mathrm{C}, \mathrm{E}$ and $\mathrm{D}$ $(p=0.001)$ and a high trans fat pattern $(p<0.001)$ associated with less and more decline over two years, respectively. These findings were independent of age, gender, education years, ApoEe4 carrier status and vascular risk factors.

\section{Conclusion}

A plasma nutrient profile high in certain vitamins and low in trans-fat may be prudent for maintaining cognitive function in older populations.

Submit your next manuscript to BioMed Central and take full advantage of:

- Convenient online submission

- Thorough peer review

- No space constraints or color figure charges

- Immediate publication on acceptance

- Inclusion in PubMed, CAS, Scopus and Google Scholar

- Research which is freely available for redistribution

\section{() Biomed Central}

\section{() Biomed Central}

